\title{
Altered Anxiety-Related Responses in Mutant Mice Lacking the $\beta 4$ Subunit of the Nicotinic Receptor
}

\author{
Ramiro Salas, Fredalina Pieri, Beryl Fung, John A. Dani, and Mariella De Biasi \\ Division of Neuroscience, Baylor College of Medicine, Houston, Texas 77030
}

\begin{abstract}
Nicotine, acting at nicotinic acetylcholine receptors (nAChRs), is the primary addictive component of tobacco. Smokers often report an anxiolytic effect of cigarettes. This relief of anxiety, attributed to nicotine, is an important contributor to relapse when smokers try to quit. Hence, the study of the anxiolytic effects of nicotine is important for understanding the mechanisms underlying nicotine addiction. Mammalian nAChRs are pentameric ion channels usually composed of $\alpha$ and $\beta$ subunits. Taking advantage of $\beta 4$-homozygous-null mice $(\beta 4-1-)$, we examined the role of the $\mathrm{nAChR} \beta 4$ subunit in anxiety-related behaviors. The $\beta 4-1-$ mice behaved as though they were less anxious than wild-type littermates on the elevated-plus and staircase mazes, tests that measure anxiety-related behaviors. To obtain an independent, physiological indication of the stress produced by several tests, we measured changes in heart rate using telemetry. Consistently with the behavioral phenotype, $\beta 4-/-$ mice had a smaller heart rate increase in the elevated-plus maze than did wild-type littermates. In contrast, during social isolation, a separate test for anxiety, $\beta 4-1-$ mice exhibited a greater increase in heart rate than did wild-type littermates. Finally, $\beta 4-I-$ mice were indistinguishable from their wild-type littermates in the open field, the light/dark box, and the mirrored chamber. The overall results demonstrate that $\beta 4$-containing $\left(\beta 4^{\star}\right) \mathrm{nAChRs}$ influence behavioral responses during anxiety-related tests, and that this effect depends on the type of anxiety-provoking experience. Through their influence on anxiety-related behavior, $\beta 4^{\star}$ nAChRs might influence both tobacco consumption and smoking relapse.
\end{abstract}

Key words: nicotinic acetylcholine receptors; $\beta 4$ subunit; anxiety; elevated-plus maze; open field; light/dark box; telemetry; heart rate

\section{Introduction}

Neuronal nicotinic acetylcholine receptors (nAChRs) are pentameric ligand-gated cation channels that mediate the addictive properties of nicotine (Dani and De Biasi, 2001). In mammals, eight $\alpha$ ( $\alpha 2$ to $\alpha 7, \alpha 9$, and $\alpha 10$ ) and three $\beta$ ( $\beta 2$ to $\beta 4$ ) subunits have been cloned (Sargent, 1993; Elgoyhen et al., 1994, 2001; McGehee and Role, 1995; Lindstrom et al., 1996; Tassonyi et al., 2002). Most nAChRs are composed of $\alpha$ and $\beta$ subunits. $\alpha 7$ can form either homopentamers or $\alpha \beta$ heteropentamers (Seguela et al., 1993; Khiroug et al., 2002), and $\alpha 9$ and $\alpha 10$ are believed to assemble as $\alpha$-only heteropentamers (Elgoyhen et al., 2001; Sgard et al., 2002). Neuronal nAChRs have been implicated in processes such as memory (Levin and Simon, 1998), anxiety (File et al., 2000; Ross et al., 2000), sleep control (Domino and Yamamoto, 1965; Salin-Pascual et al., 1999), antinociception (Marubio et al., 1999), and autonomic nervous system function (Xu et al., 1999a,b; De Biasi, 2002). Nicotinic receptors may also be involved in neurological disorders such as nocturnal epilepsy, schizophrenia, Parkinson's disease, and Alzheimer's disease (Levin and Simon, 1998; Rusted et al., 2000; Dani and De Biasi, 2001; Leonard et al., 2001; Moulard, 2001).

A number of nicotinic receptor-mutant mice has been generated by various groups, and their analysis has shed light on the

\footnotetext{
Received Aug. 16, 2002; revised April 23, 2003; accepted April 30, 2003.

This work was supported by National Institute on Drug Abuse Grants DA12661 and DA09411, National Institute of Neurological Disorders and Stroke Grant NS21229, American Heart Association of Texas Grant 0150808Y, the Whitaker Foundation, and the US-Israel Binational Science Foundation.

Correspondence should be addressed to Dr. Mariella De Biasi, Division of Neuroscience, Baylor College of Medicine, Houston, TX 77030. E-mail: debiasi@bcm.tmc.edu.

Copyright $\odot 2003$ Society for Neuroscience $\quad 0270-6474 / 03 / 236255-09 \$ 15.00 / 0$
}

functions of different nAChR subunits: $\alpha 3$ (Xu et al., 1999a; Yu et al., 2000), $\alpha 4$ (Marubio et al., 1999; Ross et al., 2000; Labarca et al., 2001), $\alpha 5$ (N. Wang et al., 2002; Salas et al., 2003), $\alpha 6$ (Champtiaux et al., 2002), $\alpha 7$ (Orr-Urtreger et al., 1997; Paylor et al., 1998; Franceschini et al., 2000, 2002; Broide et al., 2002), $\beta 2$ (Picciotto, 1995; Zoli et al., 1999; Cohen et al., 2002; Shoaib et al., 2002), $\beta 2 / \beta 4$ (Xu et al., 1999b), and $\beta 3$ (Booker et al., 2000). A recurrent behavioral phenotype among $n A C h R-$ mutant mice is a difference in anxiety-like responses on the elevated-plus maze with little if any effect on other anxiety tests, as revealed by the analysis of $\beta 3$ - and $\alpha 4$-mutant mice (Booker et al., 2000; Ross et al., 2000; Labarca et al., 2001).

Nicotine has been shown to affect anxiety in different ways (Picciotto et al., 2002). In rodents, nicotine can be anxiolytic, anxiogenic, or have no effect on anxiety, depending on the dose used and the route of administration, even when the same behavioral test is performed (Cheeta et al., 2000; File et al., 2000). In humans, according to smokers' accounts, smoking may have anxiolytic effects, which are likely attributable to the nicotine contained in cigarettes (Kassel and Unrod, 2000). However, despite the reported anxiolytic effect of cigarettes, smokers display higher scores in anxiety-related tests than nonsmokers and smokers who quit (Parrott, 1995).

The $\beta 4$ subunit of nicotinic receptors is widely expressed in the peripheral nervous system, but in the rat CNS, it is restricted to a few regions (Duvoisin et al., 1989; Dineley-Miller and Patrick, 1992; Poth et al., 1997; Xu et al., 1999b). We show here that, in the mouse, the CNS expression pattern of $\beta 4$ is even more restricted than in the rat, with its expression significantly detected only in the olfactory bulb (Olf), medial habenula (MHb), pineal 
gland (Pin), interpeduncular nucleus (IPN), and inferior colliculus (IC). To date, no specific function for CNS $\beta 4$-containing $\left(\beta 4^{*}\right)$ nAChRs has been reported. Our data show that $\beta 4-/-$ mice display behavioral differences when compared with their wild-type $(\beta 4+/+)$ littermates on anxiety-related tests. The $\beta 4-/-$ mice showed increased exploratory behavior in the elevated-plus maze and increased climbing activity in the staircase maze, suggesting decreased anxiety-like behavior. Conversely, social isolation was more anxiogenic in the $\beta 4-/-$ mice. The behavior in the open field, light/dark box, and mirror chamber was unchanged.

\section{Materials and Methods}

Animals. $\beta 4^{-1-}$ mice were generated as described previously (Xu et al., $1999 b)$. Experiments were performed on mice backcrossed for six generations into the $\mathrm{C} 57 \mathrm{BL} / 6 \mathrm{~J}$ background. All of the tests were performed on 2- to 7-month-old animals of both sexes. Mice were housed (three to five per cage) under a $12 \mathrm{hr}$ light/dark cycle with ad libitum access to food and water. Behavioral experiments were performed during the light phase. The experimenters were blind to the genotypes until data were gathered. $\beta 4+/+, \beta 4+/-$, and $\beta 4-/-$ mice were generated by crossing heterozygous mice. We used all of the $\beta 4+/+$ and $\beta 4-/-$ and some of the $\beta 4+/-$ littermates from each litter. As reported previously, $\beta 4-/-$ mice do not show any obvious physical or neurological deficits (Xu et al., 1999b). In the behavioral experiments, a minimum of 15 mice per genotype was used on each replication, and the experiments were done in two separate batches of mice. For clarity and space, the data from both replications of the behavioral experiments were pooled after confirming that both groups showed the same results (including statistical significance in the elevated-plus and staircase mazes). Groups of 14-21 mice were used in the telemetry experiments. All of the procedures were approved by the Baylor College of Medicine Animal Research Committee and followed the guidelines for animal intramural research from the National Institutes of Health.

In situ hybridization. Probes for in situ hybridization were cloned by reverse transcription-PCR using total RNA isolated from a mouse septal neuroblastoma cell line (SN56 cells) (Blusztajn et al., 1992). The primers were designed from the published rat sequences to encompass the third intracellular loop of each subunit. The template DNA segments and sizes were as follows: $\alpha 4$ (1046-1789; 743 bp), $\beta 4$ (1056-1428; 372 bp), and $\beta 3$ (1119-1566; 447 bp). PCR fragments were subcloned into pBluescript and sequenced (Franceschini et al., 2002). In situ hybridization with $\left[{ }^{35} \mathrm{~S}\right] \mathrm{UTP}$ (DuPont NEN, Boston, MA) riboprobes was performed as described previously (Broide et al., 1996). Quantitation of in situ signals was performed as described previously (Broide et al., 2002).

Locomotor activity in the open field. Mice were placed in a clear Plexiglas arena $(40 \times 40 \times 40 \mathrm{~cm})$, and locomotor activity was measured over a 30 min session using a computer-operated Ethovision system (Noldus, Wageningen, The Netherlands). This system was also used in all of the other behavioral experiments. The total distance moved in the arena and the distance moved in a center square $(20 \times 20 \mathrm{~cm})$ were recorded. The ratio of the distance moved in the center to the total distance moved was calculated and used as a measure of anxiety-related behavior (Paylor et al., 1998).

Light/dark exploration. The light/dark exploration test, which is believed to measure anxiety-related behavior (Crawley, 1980) was performed by placing the mouse in a cage $(44 \times 21 \times 21 \mathrm{~cm})$ that has two chambers, one bigger and bright, and the other smaller and dark. The animal was initially placed in the lighted side, and transitions between sides and the time spent in each division were recorded for $10 \mathrm{~min}$.

Elevated-plus maze. Mice were placed for $5 \mathrm{~min}$ on an elevated-plus maze consisting of four arms $(25 \times 7 \mathrm{~cm})$, two with high, black walls (15 $\mathrm{cm}$ high), and two without walls. Mice were placed in the intersection between the arms $(7 \times 7 \mathrm{~cm})$, and the number of entries into, and the time spent in, the open and closed arms were recorded. These two parameters were taken as measures of anxiety-related behavior (Pellow et al., 1985). For some animals, the experiment was repeated $1 \mathrm{~d}$ later (trial 2).

Mirror chamber. For the mirror chamber test (Toubas et al., 1990), mice were placed in a black chamber $(30 \times 30 \times 40 \mathrm{~cm})$ located inside another chamber $(40 \times 40 \times 40 \mathrm{~cm})$. The interior walls, floor, and ceiling of the inside chamber are mirrors, and there is also a mirror in the internal wall of the bigger chamber that is facing the entrance of the mirrored box. Mice were placed on a corner opposite to the entrance, and their movement was monitored for $5 \mathrm{~min}$. Entrances into the mirrored chamber, as well as the time spent in the mirrored chamber, were recorded. Entrances into the two lateral corridors were recorded and used as control for total activity.

Staircase maze. The staircase maze test, which is also sensitive to anxiety-related drug treatments and behaviors, was performed as described previously (Simiand et al., 1984; Weizman et al., 1999). Briefly, mice were placed for $3 \mathrm{~min}$ in the staircase, a rectangular $(45 \times 10 \mathrm{~cm})$ maze that has six steps $(10 \times 7.5 \mathrm{~cm}, 2.5 \mathrm{~cm}$ high $)$. We recorded rearing and step climbing (defined as four paws on the next step), because these behaviors have been shown to be decreased in mice showing anxious-like behavior (Simiand et al., 1984; Weizman et al., 1999).

Telemetry. Radiotelemetry implants (TAEA-F20; Data Sciences, St. Paul, MN) were used to monitor heart rate (HR) in conscious, freely moving animals. The body of the implants was inserted into the abdominal cavity of anesthetized animals, and the leads were positioned in a lead II electrocardiogram configuration. Animals were allowed a $9 \mathrm{~d}$ recovery period during which weight and food intake were monitored. After recovering from surgery, an implanted mouse was housed with at least two same-sex littermates (home cage), and its HR was monitored for $48 \mathrm{hr}$, taking one measurement every 2 or $10 \mathrm{~min}$. The animal was then transferred to another cage in which it was kept in isolation for $48 \mathrm{hr}$ (single cage) while HR was monitored. After the isolation period, the mouse was returned to its home cage, and HR was monitored until it returned to basal levels (usually within $24 \mathrm{hr}$ ).

Light/dark box and elevated-plus tests on telemetry-implanted mice. Behavioral tests were conducted at least $2 \mathrm{~d}$ after the social isolation experiment was finished, and the heart rate returned to pretest levels. For the light/dark box test, basal heart rate was measured for $30 \mathrm{~min}$ before the beginning of the experiment. The animals were then allowed to freely explore the box for $20 \mathrm{~min}$. During this time, the behavior of the animals was recorded on tape. After the test, mice were returned to their cage, and HR was monitored for another hour. The average HR for the $20 \mathrm{~min}$ the mouse spent in the light/dark box was compared with the average HR during baseline. In addition, we compared average HR in the box with the average HR obtained when the mouse was exploring the lighted chamber. At least $1 \mathrm{~d}$ after the light/dark box experiment, the implanted mice were tested in the elevated-plus maze. Basal HR was recorded for 30 min before placing the mice in an elevated-plus maze. The receiver for telemetry was placed above the maze. Because of spatial constraints of the receiver, the closed arms of the maze were $7 \mathrm{~cm}$ shorter than in the previous experiments. Mice were placed into the elevated-plus maze and allowed to explore it for $20 \mathrm{~min}$ while the HR was monitored. The animals were subsequently returned to their home cage, and HR was monitored for 1 additional hr.

Data acquisition and analysis. Behavioral data were analyzed using Excel (Microsoft; Redmond, WA) or Statistica (StatSoft, Tulsa, OK), and unpaired Student's $t$ test or ANOVA and Newman-Keuls post hoc comparisons. Differences were considered significant when $p<0.05$. The HR data were collected using the Dataquest ART version 1.10 system (Data Sciences). The HR parameter files were exported and analyzed using SigmaPlot 4.1 (SPSS, Chicago, IL) and ANOVA.

\section{Results}

\section{Expression pattern of the $\beta 4 \mathrm{nAChR}$ subunit mRNA in the CNS}

The expression pattern of $\beta 4$ mRNA in the mouse brain is shown in Figure 1. From rostral to caudal, the regions of expression were as follows. Relatively high levels of $\beta 4$ expression were found on the olf (Fig. 1A). The $\beta 4$ signal was restricted to mitral cells, which are the main input-output cells of the olfactory bulb. We found very high levels of $\beta 4 \mathrm{mRNA}$ in the MHb (Fig. 1D), whereas the IPN showed lower levels of $\beta 4$ subunit mRNA $(G)$. Along with the MHb, the pineal gland (Fig. $1 \mathrm{~J}$ ) expressed the 


\section{$\beta 4$ mRNA}

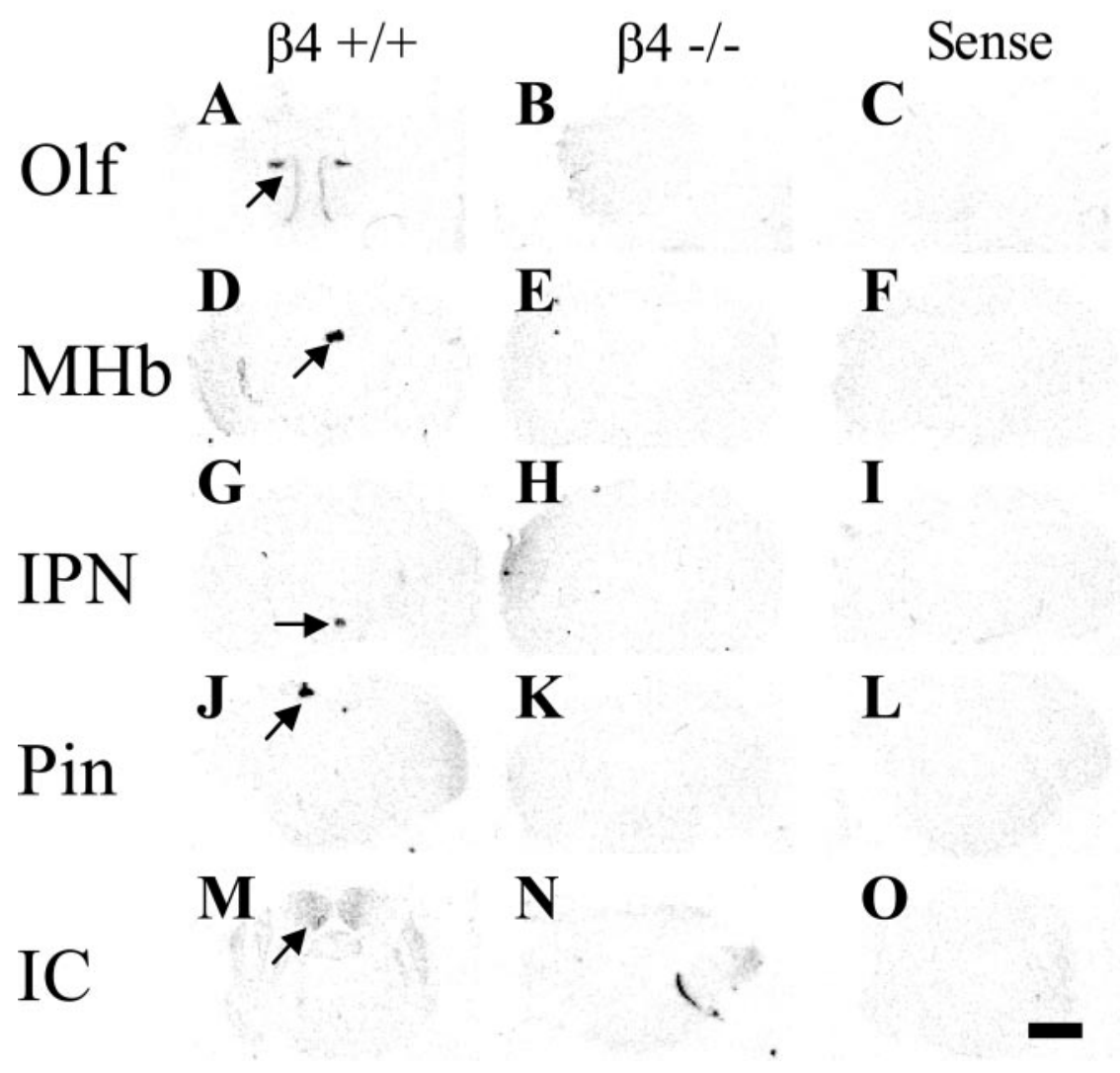

Figure 1. Expression of $\beta 4 \mathrm{mRNA}$ in the mouse brain. $A, D, G, J, M$, Distribution of $\beta 4 \mathrm{nAChR} m R N A$ in $\beta 4+/+$ brain. Arrows indicate the mRNA signal. $B, E, H, K, N$, Distribution of $\beta 4 \mathrm{nAChR} m \mathrm{mRN}$ in $\beta 4-/-$ brain. $C, F, I, L, O$, Control experiments performed with sense probe on $\beta 4+/+$ brains. $A-C$, Olfactory bulb (Olf). $D-F$, Medial habenula (MHb). G-I, Interpeduncular nucleus (IPN). J-L, Pineal gland (Pin). M-O, Inferior colliculus (IC). Scale bar, $2 \mathrm{~mm}$.

highest levels of $\beta 4 \mathrm{mRNA}$, in agreement with previous results in rat tissue (Duvoisin et al., 1989; Dineley-Miller and Patrick, 1992; Zoli et al., 1995). Detectable, low levels of $\beta 4$ subunit mRNA were also found in the inferior colliculus (Fig. $1 M$ ), which is the main target for MHb neurons. In $\beta 4-/-$ mice, no $\beta 4$ mRNA was detected (Fig. $1 B, E, H, K, N$ ). Sense controls showed no specific signal (Fig. $1 C, F, I, L, O$ ). Three $\beta 4+/+$ and three $\beta 4-/-$ mouse brains were used for these experiments. Representative brain sections are shown for each genotype. The sense probe was used on $\beta 4+/+$ brains only.

Several anxiety-related tests show no effect of the $\beta 4$ genotype In the open-field test, the total distance traveled by the mouse is a measure of locomotion and activity, and the ratio of the distance traveled in the center to the total distance is a measure of exploration and anxiety-like behavior. In this experiment, $\beta 4-/-$ mice and littermate controls exhibited similar activity and center distance/total distance ratios. Therefore, in the open-field test, $\beta 4-/-$ mice revealed normal exploratory activity and anxietyrelated behavior (Fig. $2 A, B$ ).

In the light/dark exploration test, the number of transitions between the dark and lighted compartments and the time spent in the light are measures of anxiety-like behavior (Crawley, 1980). The $\beta 4-/-$ mice and their $\beta 4+/+$ littermates showed no statistically significant differences in the number of transitions between the lighted and the dark compartments, or in the time spent in the dark compartment (Fig. 2C,D).

In the mirror chamber test, the animal chooses between staying in a black corridor and entering a chamber with mirrored walls, floor, and ceiling (Toubas et al., 1990). The number of entries and the time spent in the anxiety-provoking mirror chamber are recorded. The $\beta 4-/-$ mice and littermate controls showed no statistically significant differences in entries and time spent in the mirror chamber (Fig. 2E,F).

\section{$\beta 4-/-$ mice show anxiety-related differences in the elevated-plus maze and the staircase maze}

The elevated-plus maze is used to analyze anxiety-related behavior on the basis of the hypothesis that there is greater stress from being in the open arms versus the closed arms of an elevated maze. The number of entrances into the open arms and the time spent in the open arms provide indications of anxiety-like behavior, and the total number of entrances into all of the arms is a measure of total activity (Pellow et al., 1985). $\beta 4-/-$ mice showed a significant increase in both the time spent and the number of entrances into the open arms (Fig. 3), with no differences in total number of entrances. The $\beta 4-/-$ mice not only entered the open arms more often (Fig. $3 A$ ), but also stayed longer after entry ((Fig. $3 B)$. This result was the first behavioral phenotype found for $\beta 4-1-$ mice, and it suggests that these animals have lower levels of anxiety-like behavior as measured in this particular test. We also tested $\beta 4+/-$ mice in the elevated-plus maze and analyzed the data using ANOVA and Newman-Keuls post hoc comparisons (open time, $F_{(2,0.05)}=9.35$; entry ratio, $F_{(2,0.05)}=$ 4.31). The results on heterozygous mice were similar to those of the $\beta 4-/-$ animals (Fig. 3).

Previous research has shown that, when nicotine is injected directly into the hippocampus, it does not affect performance in the elevated-plus maze on the first trial, but nicotine has anxiolytic effects on a second trial performed at least $1 \mathrm{~d}$ after the first trial (Cheeta et al., 2000). On the basis of that observation, we repeated the elevated-plus experiment $1 \mathrm{~d}$ after the first trial in the maze. The results showed that mice made fewer entries and stayed for shorter times in the open arms on trial 2, but the $\beta 4$ genotype still had the same influence as on trial 1 . The time spent in the open arms dropped from $25 \pm 5 \mathrm{sec}$ (mean \pm SEM) on trial 1 to $6 \pm 2 \mathrm{sec}$ on trial 2 for $\beta 4+/+$ mice, and from $66 \pm 6 \mathrm{sec}$ to $23 \pm 4 \mathrm{sec}$ for $\beta 4-/-$ mice. A similar result was observed in the percentage of entries in the open arms, which dropped from $41 \%$ \pm 7 to $14 \% \pm 3$ for $\beta 4+/+$ mice, and dropped from $63 \% \pm 6$ to $30 \% \pm 4$ for $\beta 4-/-$ animals. These data were analyzed using Student's $t$ test. The percent change in arm entries and time between days 1 and 2 was not statistically different between $\beta 4+/+$ and $\beta 4-/-$ mice. These results indicate that mice explore less the second day, but this difference is similar in $\beta 4+/+$ and $\beta 4-/-$ mice. Hence, habituation to the maze is normal in $\beta 4$ - 

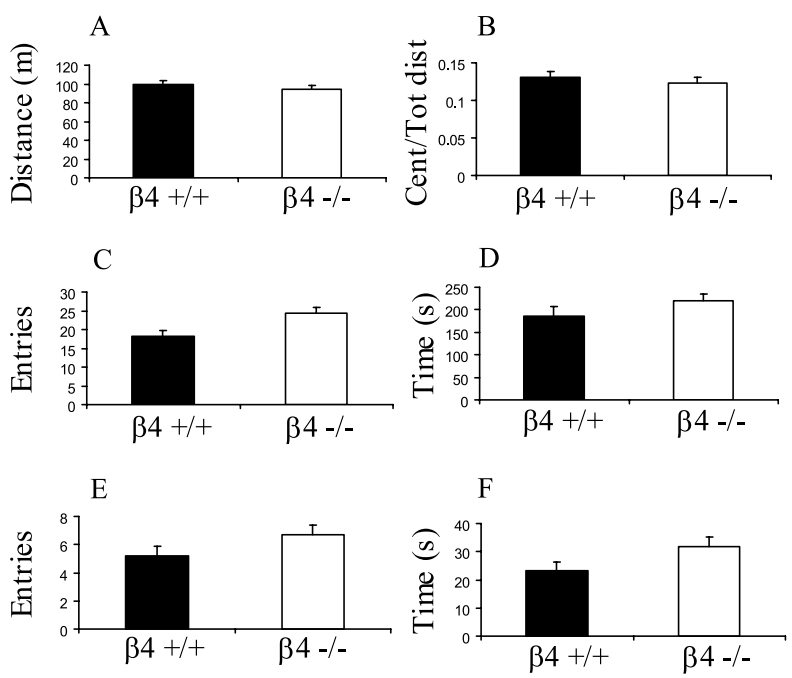

Figure 2. Open-field, light/dark, and mirror chamber tests. $A$, 0pen-field test $(\beta 4+/+$, $n=39 ; \beta 4-/-, n=31)$, total distance traveled. $B$, Open-field test, distance in the center (Cent)/total distance (Tot dist) ratio. C, Light/dark test $(\beta 4+/+, n=45 ; \beta 4-/-, n=39)$, number of entries into the dark chamber. $D$, Light/dark test, time spent in the lighted chamber. $E$, Mirror chamber test $(\beta 4+/+, n=40 ; \beta 4-/-, n=60)$, entries into the mirror chamber. $F$, Mirror chamber test, time spent in the mirror chamber. Averages ( \pm SEM) are shown for $\beta 4+/+$ (filled bars) and $\beta 4-/-$ (open bars) mice, respectively.

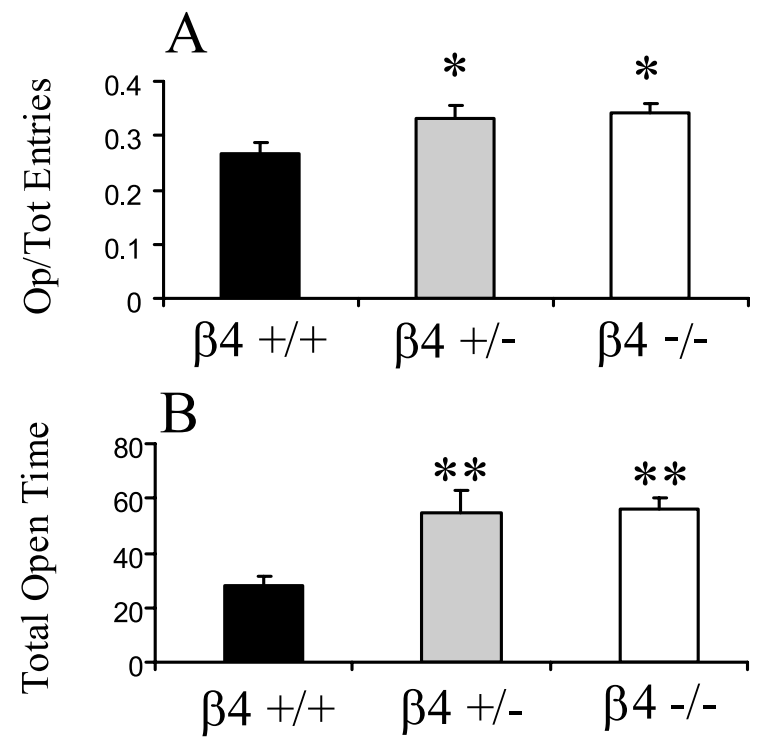

Figure 3. Elevated-plus test. $A$, Open (Op) entries/total (Tot) entries. $B$, Total time spent in the open arms (Total Open Time). Averages ( \pm SEM) are shown. $\beta 4+/+$, (black bars) $n=34$; $\beta 4+1-$, (gray bars) $n=29 ; \beta 4-1-$, (open bars) $n=46$. ${ }^{*} p<0.01 ;{ }^{* *} p<0.005$, compared with $\beta 4+/+$.

mutant mice, and the behavior observed is likely to be attributable to decreased anxiety-like behavior and not to abnormal learning or habituation to the maze.

The staircase maze (Simiand et al., 1984) is another test for anxiety-related behavior that has been validated using different anxiolytics (Pick et al., 1997; Weizman et al., 1999). In this test, mice explore a rectangular maze that has six steps. The number of steps climbed and the rearing behavior of the mice are recorded as measures of anxiety-related behavior. The $\beta 4-/-$ mice displayed significantly more steps up and rearing events than did the $\beta 4+/+$ littermates (Fig. 4). The data were analyzed using
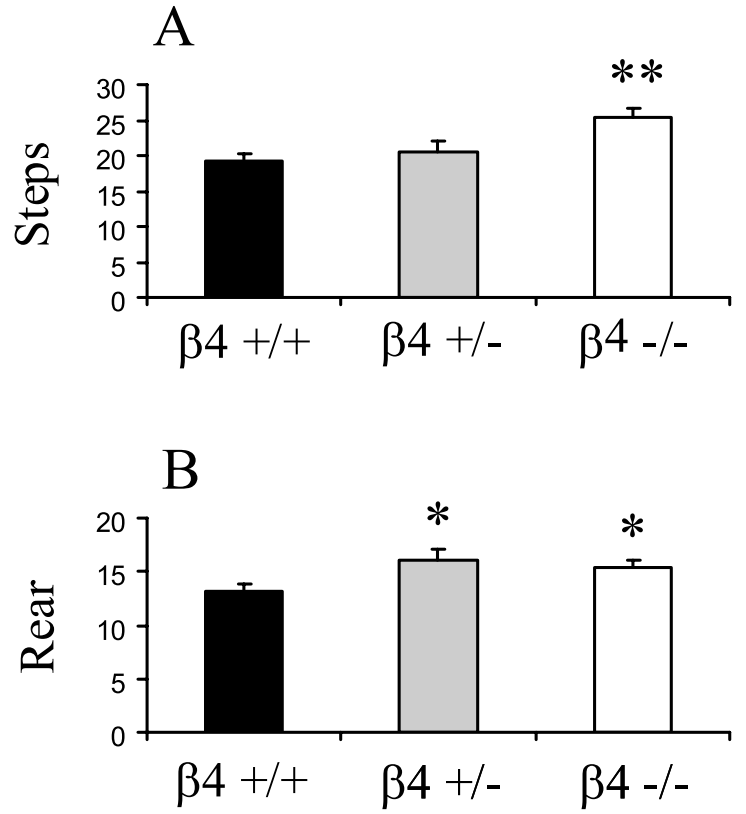

Figure 4. Staircase maze. $A$, Total number of steps climbed (Steps). B, Rearing events (Rear). Averages ( \pm SEM) are shown for $\beta 4+/+$ (black bars; $n=54), \beta 4+/-($ gray bars; $n=40)$, and $\beta 4-/-$ (open bars; $n=60$ ), respectively. ${ }^{*} p<0.05$, compared with $\beta 4+/+{ }^{* *} p<$ 0.01 .

ANOVA and Newman-Keuls post hoc comparisons (steps, $F_{(2,0.05)}=7.41$; rearing $\left.F_{(2,0.05)}=3.69\right)$. This result is consistent with our experiments in the elevated-plus maze.

\section{Heart rate changes confirm the behavioral results}

There is a large body of literature in humans that correlates emotions and anxiety with the activation of the autonomic nervous system (Berntson et al., 1998; Friedman and Thayer, 1998; Johansen-Berg and Walsh, 2001; O'Connor et al., 2002; Watkins et al., 2002). Such activation is reflected by changes in heart rate and blood pressure, among other factors. To obtain an independent measurement of anxiety-related effects, we monitored HR changes during the elevated-plus and the light/dark-box tests. By directly measuring HR without the confounds of handling or restraint, telemetry gives a quantitative, nonsubjective measure of a parameter (HR) that is linked to changes in anxiety-related behavior (Tornatzky and Miczek, 1995; Southwick et al., 1999; Bouwknecht et al., 2000). As shown in Figure 5A, basal HR was statistically the same for $\beta 4+/+$ and $\beta 4-/-$ mice, and HR increases observed when the animals are placed in the light/dark maze were comparable. We also measured the mean HR of the mice when they were in the lighted region of the maze, and compared that with the average HR in the maze. Both $\beta 4+/+$ and $\beta 4-/-$ mice had increased HR while they explored the lighted chamber, and these increases were not statistically different. For $\beta 4+/+$ mice, the average HR in the lighted chamber was $21 \pm 7$ beats per minute (bpm) higher than the average HR during the total time the mice spent in the light/dark box. For the $\beta 4-/-$ mice, the average HR increase in the lighted chamber was $30 \pm 15$ bpm. Increases in HR were also observed in the elevated-plus maze, but the increase in HR was significantly lower for $\beta 4-/-$ mice than for $\beta 4+/+$ mice $(p<0.001)$ (Fig. $5 B)$. Differences in basal heart rate across genotypes or experiments were not statistically significant $\left(\beta 4+/+\right.$, light/dark box, $\mathrm{HR}_{\text {basal }}=485 \pm 26 \mathrm{bpm}$; $\beta 4+/+$, elevated plus, $H_{\text {basal }}=517 \pm 40 \mathrm{bpm} ; \beta 4-/-$, light $/$ dark 

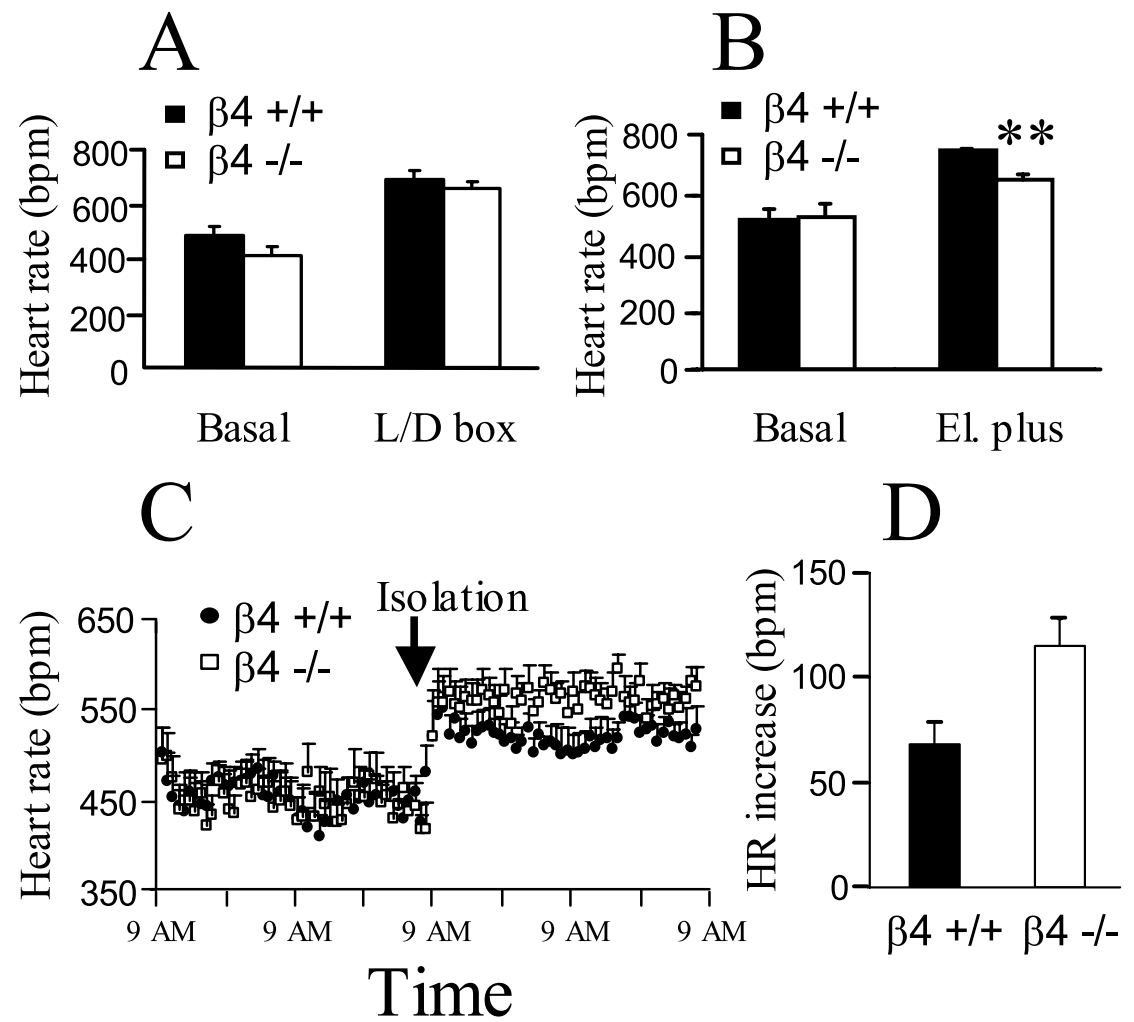

Figure 5. Telemetric measurement of HR during behavior. $A, H R$ ( \pm SEM; black bars) of $\beta 4+/+$ and $\beta 4-/-$ (white bars) mice in the light/dark (L/D) box $(\beta 4+/+, n=9 ; \beta 4-/-, n=5)$. No statistically significant differences were seen between $\beta 4+/+$ and $\beta 4-/-$ mice in average basal HR or HR during maze exploration. $B, H R$ of $\beta 4+/+$ and $\beta 4-/-$ mice in the elevated-plus (El. plus) maze. Statistically significant differences were observed in HR during maze exploration but not in basal HR. No statistically significant differences were found among any of the four basal HRs from $A$ and $B$. C, HR of $\beta 4+/+$ and $\beta 4-/-$ mice during social isolation $(\beta 4+/+, n=12 ; \beta 4-/-, n=9)$. $D$, Average increase ( \pm SEM) in heart rate after social isolation for $\beta 4+/+$ and $\beta 4-/-$ mice. ${ }^{* *} p<0.001 ;{ }^{*} p<0.05$.

box, $\mathrm{HR}_{\text {basal }}=411 \pm 32 \mathrm{bpm} ; \beta 4-/-$, elevated plus, $\mathrm{HR}_{\text {basal }}=$ $528 \pm 49 \mathrm{bpm} ; p>0.05)$. These data agree with the behavioral data shown previously. In the light/dark test, the behavior and HR of $\beta 4-/-$ mice were normal. In the elevated-plus maze, the behavior and HR of the $\beta 4-/-$ mice were different from those of the littermate controls.

\section{Stress during social isolation increases heart rate}

Single-cage housing has been shown to produce HR increases in rats (Gardiner, 1977; Naranjo, 1985), probably because of changes in anxiety-like responses (Guidotti et al., 2001). We examined whether social isolation produces the same effect in mice, and whether that effect is dependent on the $\beta 4$ genotype. The HR of $\beta 4+/+$ and $\beta 4-/-$ mice was measured during normal housing conditions (three to five littermates per cage) and under social isolation (one mouse per cage). Animals were monitored for much longer periods of time than in any of the other behavioral tests: $48 \mathrm{hr}$ in the home cage and the single cage, respectively. Over these long periods of time, $\beta 4+/+$ mice (on average) had statistically the same heart rate as $\beta 4-/-$ animals when housed with littermates: $453 \pm 18 \mathrm{bpm}$ for $\beta 4+/+$ and $451 \pm 21 \mathrm{bpm}$ for $\beta 4-/-$ mice, respectively. Under isolation, the heart rates were $524 \pm 16 \mathrm{bpm}$ for $\beta 4+/+$ and $567 \pm 17 \mathrm{bpm}$ for $\beta 4-/-$ mice $(p>0.05)$. However, although during isolation the HR increased for both genotypes (Fig. $5 D$ ), the HR of $\beta 4+/+$ mice increased significantly less $(68+10 \mathrm{bpm})$ than the $\mathrm{HR}$ of $\beta 4-/-$ mice $(115+13 \mathrm{bpm} ; p<0.05)$. The increase in heart rate was calculated by subtracting the $\mathrm{HR}$ in the home cage from the HR in isolation at each hour and averaging the 48 resulting numbers for each mouse. The $p$ value was calculated using the average for each mouse as an independent value $(+/+, n=12 ;-/-, n=9)$. This result indicates that the stress of isolation has a greater impact on $\beta 4-/-$ than on $\beta 4+/+$ mice.

nAChR subunits that influence anxietyrelated tests are coexpressed in medial habenula and interpeduncular nucleus The most common phenotype of nAChRsubunit-mutant mice is associated with anxiety-producing tests, especially the elevated-plus test. $\beta 4-/-, \quad \beta 3-/-$, $\alpha 4-/-$, and $\alpha 4$ gain-of-function ( $\alpha 4$ L9'S-heterozygous) mice all have a significant phenotype in the elevated-plus maze. If there is a specific brain area that influences the anxiety-related behaviors manifested in the elevated-plus maze, the nAChR subunit implicated in such behavior shouldbe coexpressed in this area. To test this hypothesis, we used the in situ hybridization technique to determine where in the mouse brain $\alpha 4, \beta 3$, and $\beta 4$ are coexpressed. Figure 6 shows the expression of $\alpha 4$ in the same brain areas in which $\beta 4$ was found (Fig. 1). No $\alpha 4$ was found in the mitral cells of the Olf (Fig. 6A, arrows point to the site of expression of $\beta 4$ ) or the Pin $(J)$. However, $\alpha 4$ and $\beta 4$ are both expressed in the MHb, the IPN, and the inferior colliculus (Fig. $6 D, G, M$ ). In $\beta 4-/-$ mice, the expression pattern of $\alpha 4$ remains the same, which argues against the possibility of subunit compensation (Fig. $6 B, E, H, K, N)$. No specific signal was observed when sections were probed with sense $\alpha 4$ probe (Fig. 6C,F,I,L,O).

Figure 7 shows the expression pattern of $\beta 3$ mRNA in the brain areas in which $\beta 4$ was found (Fig. 1). Arrows point to the sites of expression of $\beta 4$. Again, the MHb (Fig. 7D) and IPN ( $G$ ) are sites of coexpression, but no $\beta 3$ was observed in the Olf, the Pin, or the IC $(A, J, M)$. No differences were observed between $\beta 4+/+$ and $\beta 4-/-$ mice (Fig. $7 B, E, H, K, N$ ), excluding the occurrence of subunit compensation in $\beta 4$ mutant mice, at least at the level of mRNA. Sense controls showed no signal (Fig. $7 C, F, I, L, O)$.

The results indicate that the only areas in which $\alpha 4, \beta 3$, and $\beta 4$ are significantly coexpressed are the MHb and the IPN. To verify that the expression of $\beta 3$ and $\alpha 4$ was unchanged in $\beta 4-/-$ mice, we performed quantitative in situ hybridization. Sections from three to four brains from $\beta 4+/+$ and $\beta 4-/-$ mice were exposed below saturation of signal, and specific areas were chosen for densitometry. Table 1 shows that $\beta 4+/+$ and $\beta 4-/-$ mice express similar amounts of $\beta 3$ and $\alpha 4$ mRNA in the areas of the brain selected for the study.

\section{Discussion}

Our investigation of the anxiety-related behaviors in $\beta 4 \mathrm{nAChR}$ mutant mice was motivated by two observations. First, human smokers often mention the anxiolytic effect of cigarettes, likely arising from nicotine, as a driving force to continue smoking 
(Parrott, 1995; Kassel and Shiffman, 1997; Stewart et al., 1997; Kassel and Unrod, 2000). Second, recent experiments on different nAChR-mutant mice suggested a link between nAChRs and anxiety-related behavior. It has been reported that $\alpha 4-/-$ mice behave as though they are more anxious than control mice in the elevated plus, whereas they are normal in a series of basic behavioral tests (Ross et al., 2000). In addition, a gain-of-function mutation in the $\alpha 4$ subunit that produces channels with higher conductance also alters anxiety-like behavior in the mutant mouse. Mice heterozygous for this mutation display increased anxiety-like behavior in the elevated plus and, to a lesser extent, in the mirror chamber, but there is no effect in the light/dark box (Labarca et al., 2001). Furthermore, mice lacking the $\beta 3$ nAChR subunit also behave normally in a standard battery of tests, but display decreased anxiety-related behavior in the elevated-plus maze, with a smaller effect in the mirror chamber and no effect in the light/dark box (Booker et al., 2000). Interestingly, $\alpha 7-/-$ mice have been shown to behave as if less anxious in the open field, with normal behavior in the light/dark box (Paylor et al., 1998). That report did not explore the elevated-plus maze. The fact that anxiety-related phenotypes are consistently found on the elevated-plus maze and not on open field or light/dark box should not be surprising. Factor analysis of behaviors on anxiety-related experiments in animals has shown that different tests reflect different underlying factors (File, 1992; Belzung and Le Pape, 1994; Ramos et al., 1997). Therefore, the fact that $\beta 4-/-$ and other nicotinic mutants show such a specific phenotype on the elevated-plus and not on other mazes might simply reflect the fact that these tests measure different dimensions of anxiety-like behaviors. Evidence that the measures of anxiety-like behaviors assessed in different tasks may reflect different aspects of anxietylike responses comes from not only the nAChR-mutant mice but also other animal models (Griebel et al., 1996, 1997, 2000; Andreatini et al., 2001), including mice overexpressing the corticotropin-releasing hormone (van Gaalen et al., 2002). Another possible explanation is that the effects of $\beta 4^{*} \mathrm{nAChRs}$ on anxiety appear only under the most stressful situations. For example, we demonstrated that, in wild-type mice, the heart rate increase in the elevated-plus maze is higher than that in the light/ dark box, suggesting that the elevated plus is a more stressful experience. There could be a threshold of stress beyond which $\beta 4^{\star} \mathrm{nAChRs}$ become important for the behavioral and physiological expression of anxiety. The existence of such a threshold would explain why there are differences in the elevated-plus maze but not in the open field or light/dark box.

Although the lack of the $\alpha 4$ subunit increases anxiety-like behavior on the same test in which absence of $\beta 3$ or $\beta 4$ decrease anxiety-like behavior, all three mutations are effective on the same test. This consistent specificity of the testing suggested that

\section{$\alpha 4$ mRNA}

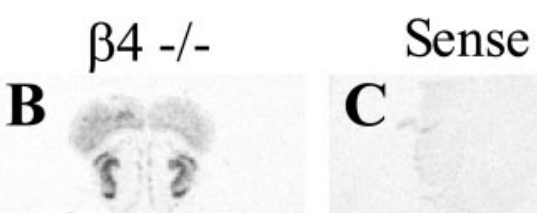

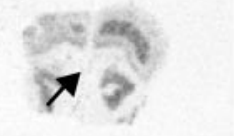
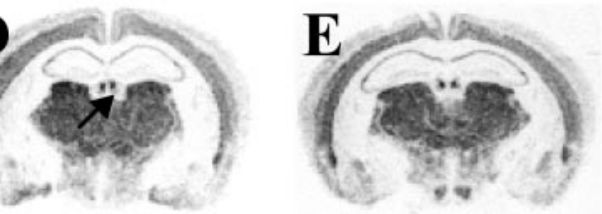

F
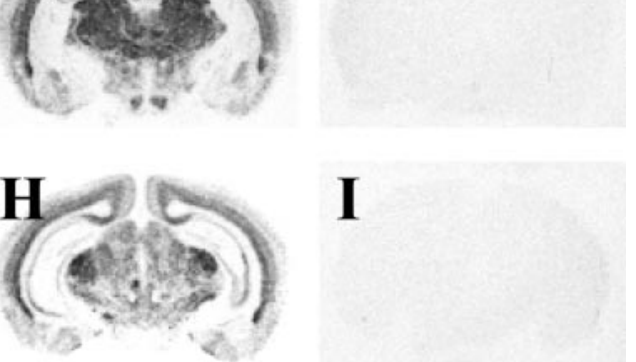

I

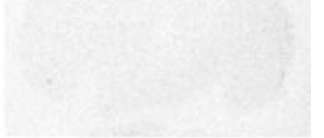

$\mathbf{L}$
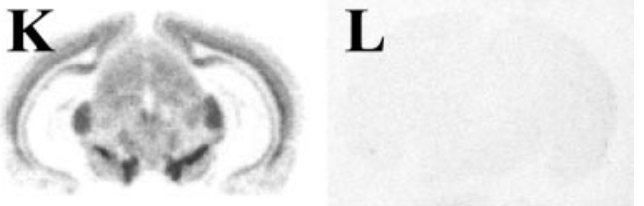

$\mathbf{O}$ $\beta 4+/+$
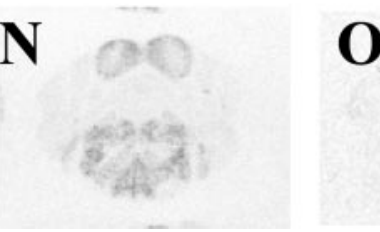

Figure 6. Expression of $\alpha 4 \mathrm{mRNA}$ at the brain levels where $\beta 4$ is expressed. $A, D, G, J, M$, Expression of $\alpha 4 \mathrm{mRNA}$ in $\beta 4+/+$ brains. Arrows indicate the site of expression of $\beta 4 . B, E, H, K, N$, Expression of $\alpha 4 \mathrm{mRNA}$ in $\beta 4-/-$ brains. $C, F, I, L, O$, Sense controls performed on $\beta 4+/+$ brains. $A-C$, Olfactory bulb (Olf). $D-F$, Medial habenula (MHb). $G-I$, Interpeduncular nucleus (IPN). J-L, Pin. $M-0$, IC. Arrows point at sites of expression of $\beta 4$. Scale bar, $2 \mathrm{~mm}$.

$\alpha 4^{\star}, \beta 3^{\star}$, and $\beta 4^{\star} \mathrm{nAChRs}$ are involved in the neuronal processing associated with the elevated-plus maze, possibly by influencing the same neuronal areas of the mouse brain. That reasoning led us to investigate where in the brain $\alpha 4, \beta 3$, and $\beta 4$ are coexpressed. The $\beta 4$ subunit was only found (at the sensitivity levels of in situ hybridization) in the mitral cells of the Olf, MHb, Pin, IPN, and IC. Within the regions in which $\beta 4$ was expressed, $\beta 3$ and $\alpha 4$ subunits were detected at significant levels only in $\mathrm{MHb}$ and IPN. This finding suggests the possibility that the MHb and its main target, the IPN, could participate in the anxiety phenotype observed in $\alpha 4, \beta 3$, and $\beta 4$ mutant mice. Indeed, nicotine injections in the dorsal raphe nucleus, which receives innervation from the habenula (Morris et al., 1999; Tomizawa et al., 2001), have been demonstrated to be anxyolitic in the rat (Cheeta et al., 2001). It has also been shown that $\beta 4^{*} \mathrm{nAChRs}$ dominate function in MHb neurons (Quick, 1999). In addition, nicotine produces a shift between the excitatory and the inhibitory actions of acetylcholine in the MHb-IPN axis: long-term exposure to low levels of nicotine leaves the inhibitory effect of muscarinic activation unaffected while decreasing the excitatory effect of nicotinic activation (Girod and Role, 2001). This effect is probably mediated by functional inactivation of presynaptic nAChRs. Therefore, it is possible that $\beta 4-/-$ mice have a constitutive lower activation of 


\section{$\beta 3$ mRNA}

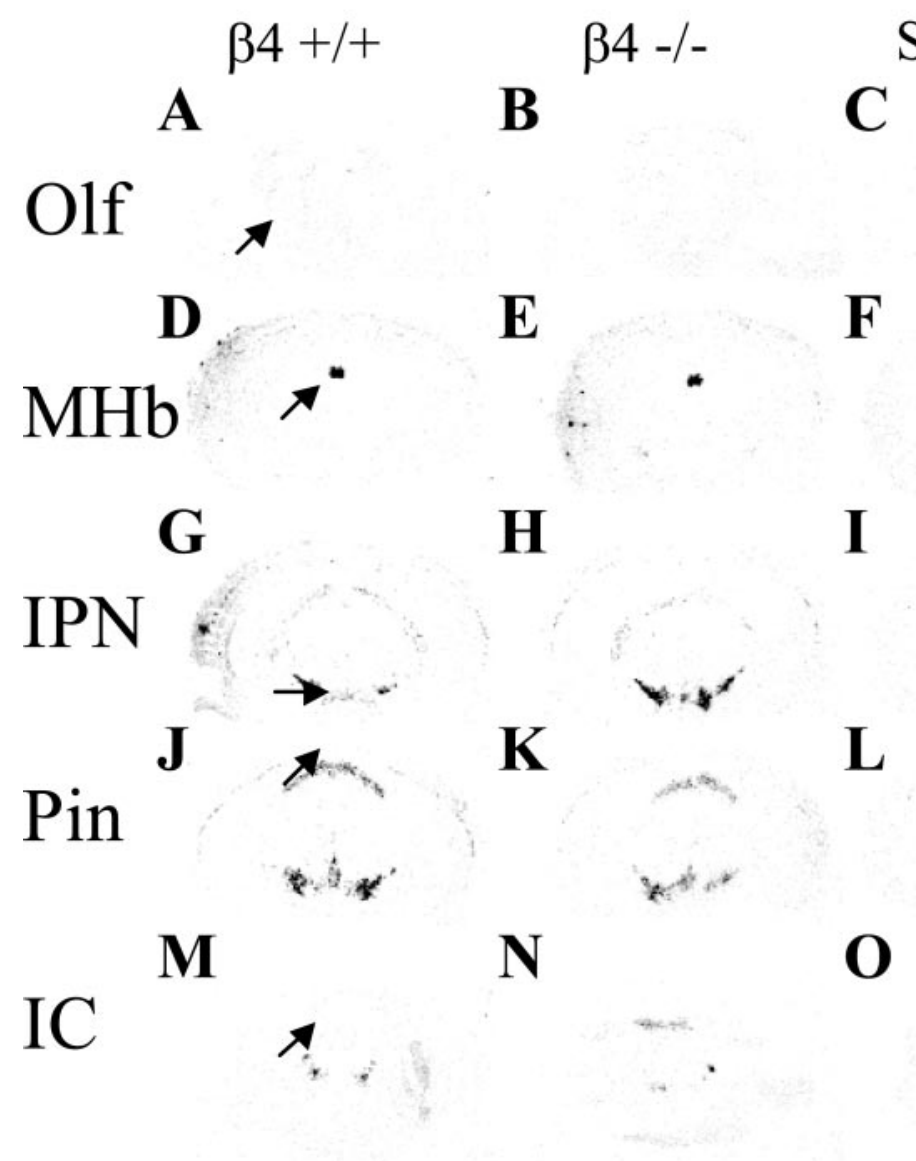

sults in an increase in both heart rate and blood pressure (Noteboom et al., 2001; Gonzalez-Bono et al., 2002). Measuring heart rate responses as an index of autonomic activation after anxiety-provoking tests in mice was therefore a natural extension of our studies. If a certain behavioral paradigm provokes anxiety, the autonomic nervous system will be activated, and the prediction is that anxiety-like behaviors correlate with increases in heart rate (Bouwknecht et al., 2000; De Biasi, 2001; X. Wang et al., 2002). Therefore, to have an independent physiological measure of anxiety-related effects, we implanted $\beta 4-/-$ mice and their control littermates with telemetry devices. This procedure was used to monitor the heart rate while mice explored the mazes. We chose the light/dark box test, because no behavioral phenotype was observed, and we chose the elevated plus, because that test showed the largest effect. We demonstrated that $\beta 4-/-$ and $\beta 4+/+$ mice have a similar increase in heart rate when exposed to the light/dark box. In contrast, $\beta 4-/-$ mice showed significantly lower increases in heart rate when mice explored the elevated-plus maze. Therefore, $\beta 4-/-$ mice behaved as though they were less anxious in the elevated plus, and they also showed a decreased physiological reaction to the maze consistent with less stress. In contrast, the heart rate responses to social isolation seem to be enhanced in $\beta 4-/-$ mice, which suggests that different stressors may act through different neuronal systems.

Because the $\beta 4 \mathrm{nAChR}$ subunit is highly expressed in the autonomic ner-

IPN function. Heavy smokers tend to adjust their nicotine intake to obtain constant levels of circulating nicotine during wake hours (Russell, 1989). In that sense, it is tempting to speculate that the lack of $\beta 4^{\star}$ receptors in the MHb could have, by decreasing IPN activity, one of the effects smokers seek: a decrease in anxiety levels.

There is a body of literature in humans that correlates emotions with the activation of the autonomic nervous system. This autonomic activation has been associated with changes in heart rate and blood pressure. There is also evidence in humans that different natural stressors can provoke unique configurations of cardiovascular activity. For example, fear produces a decrease in heart rate (Maschke et al., 2002), but stress-induced anxiety re- vous system (Rust et al., 1994), altered autonomic function might also influence the differences observed between wild-type and mutant mice. It is possible that the $\beta 4$-null mutation produces an overall dysregulation of the autonomic nervous system, and that heart rate responses could be attenuated or enhanced depending on the stress paradigm used. Additional experimentation will be needed to address autonomic function in $\beta 4-/-$ mice in basal conditions and during stress.

In conclusion, we showed that the lack of the nAChR $\beta 4$ subunit alters the behavioral responses to certain anxiety-provoking experimental paradigms. The effect might be dependent on the

Table 1. Densitometric analysis of $\alpha 4$ and $\beta 3$ mRNA expression in various regions of $\beta 4+/+$ and $\beta 4-/-$ mouse brains

\begin{tabular}{|c|c|c|c|c|c|c|}
\hline \multirow[b]{2}{*}{ Label } & \multicolumn{6}{|c|}{ \% Wild type } \\
\hline & Cortex & CA1 & Thalamus & Medial habenula & Inferior colliculus & Substantia nigra \\
\hline \multicolumn{7}{|l|}{$\alpha 4$ mRNA } \\
\hline$+/+$ & $100 \pm 9$ & $100 \pm 14$ & $100 \pm 8$ & $100 \pm 12$ & $100 \pm 10$ & \\
\hline$-1-$ & $95 \pm 3$ & $99 \pm 6$ & $100 \pm 10$ & $102 \pm 9$ & $110 \pm 21$ & \\
\hline \multicolumn{7}{|l|}{$\beta 3$ mRNA } \\
\hline$+1+$ & & & $100 \pm 13$ & $100 \pm 7$ & & $100 \pm 12$ \\
\hline$-1-$ & & & $104 \pm 14$ & $114 \pm 2$ & & $104 \pm 4$ \\
\hline
\end{tabular}


MHb-IPN expression of the $\beta 4$ subunit. The data on $\alpha 4, \beta 3$, and $\beta 4$ coexpression might help to explain how different $\mathrm{nAChR}$ types can exert their influence on anxiety-related behavioral tests.

A major long-term goal of the nicotine addiction field is to understand how the specific nAChR subtypes contribute to the addiction process. Identifying the type and location of the $\mathrm{nAChRs}$ involved in anxiety-related behaviors could lead to therapies that aid in smoking cessation and prevention.

\section{References}

Andreatini R, Blanchard C, Blanchard R, Brandao ML, Carobrez AP, Griebel G, Guimaraes FS, Handley SL, Jenck F, Leite JR, Rodgers J, Schenberg LC, Da Cunha C, Graeff FG (2001) The brain decade in debate. II. Panic or anxiety? From animal models to a neurobiological basis. Braz J Med Biol Res 34:145-154.

Belzung C, Le Pape G (1994) Comparison of different behavioral test situations used in psychopharmacology for measurement of anxiety. Physiol Behav 56:623-628.

Berntson GG, Sarter M, Cacioppo JT (1998) Anxiety and cardiovascular reactivity: the basal forebrain cholinergic link. Behav Brain Res 94:225-248.

Blusztajn JK, Venturini A, Jackson DA, Lee HJ, Wainer BH (1992) Acetylcholine synthesis and release is enhanced by dibutyryl cyclic AMP in a neuronal cell line derived from mouse septum. J Neurosci 12:793-799.

Booker TK, Tritto T, Colman J, Cui C, Collins AC, Heinemann SF (2000) $\beta 3$ subunits in regulation of anxiety: analysis of $\beta 3$-null mutant mice. In: The 20th Neuropharmacology Conference, p 65. New Orleans: Elsevier Science.

Bouwknecht JA, Hijzen TH, van der Gugten J, Maes RA, Olivier B (2000) Stress-induced hyperthermia in mice: effects of flesinoxan on heart rate and body temperature. Eur J Pharmacology 400:59-66.

Broide RS, Robertson RT, Leslie FM (1996) Regulation of $\alpha 7$ nicotinic acetylcholine receptors in the developing rat somatosensory cortex by thalamocortical afferents. J Neurosci 16:2956-2971.

Broide RS, Salas R, Ji D, Paylor R, Patrick JW, Dani JA, De Biasi M (2002) Increased sensitivity to nicotine-induced seizures in mice expressing the L250T $\alpha 7$ nicotinic acetylcholine receptor mutation. Mol Pharmacol 61:695-705.

Champtiaux N, Han ZY, Bessis A, Rossi FM, Zoli M, Marubio L, McIntosh JM, Changeux JP (2002) Distribution and pharmacology of $\alpha 6$ containing nicotinic acetylcholine receptors analyzed with mutant mice. J Neurosci 22:1208-1217.

Cheeta S, Kenny PJ, File SE (2000) Hippocampal and septal injections of nicotine and 8-OH-DPAT distinguish among different animal tests of anxiety. Prog Neuropsychopharmacol Biol Psychiatry 24:1053-1067.

Cheeta S, Irvine EE, Kenny PJ, File SE (2001) The dorsal raphe nucleus is a crucial structure mediating nicotine's anxiolytic effects and the development of tolerance and withdrawal responses. Psychopharmacology (Berl) 155:78-85.

Cohen G, Han ZY, Grailhe R, Gallego J, Gaultier C, Changeux JP, Lagercrantz $H$ (2002) $\beta 2$ nicotinic acetylcholine receptor subunit modulates protective responses to stress: a receptor basis for sleep-disordered breathing after nicotine exposure. Proc Natl Acad Sci USA 99:13272-13277.

Crawley J (1980) Preliminary report of a simple animal behavior model for the anxiolytic effects of benzodiazepines. Pharmacol Biochem Behav 13:167-170

Dani JA, De Biasi M (2001) Cellular mechanisms of nicotine addiction. Pharmacol Biochem Behav 70:439-446.

De Biasi M (2001) Heart rate variability studies in nicotinic mutant mice. Paper presented at 19th Annual Houston Conference on Biomedical Engineering Research, Houston, Feb 8-9, 2001.

De Biasi M (2002) Nicotinic receptor mutant mice in the study of autonomic function. Curr Drug Targets 1:409-414.

Dineley-Miller K, Patrick J (1992) Gene transcripts for the nicotinic acetylcholine receptor subunit, $\beta 4$, are distributed in multiple areas of the rat central nervous system. Brain Res Mol Brain Res 16:339-344.

Domino EF, Yamamoto KI (1965) Nicotine: effect on the sleep cycle of the cat. Science 150:637-638.

Duvoisin RM, Deneris ES, Patrick J, Heinemann S (1989) The functional diversity of the neuronal nicotinic acetylcholine receptors is increased by a novel subunit: $\beta 4$. Neuron 3:487-496.

Elgoyhen AB, Johnson DS, Boulter J, Vetter DE, Heinemann S (1994) $\alpha 9$ : an acetylcholine receptor with novel pharmacological properties expressed in rat cochlear hair cells. Cell 79:705-715.

Elgoyhen AB, Vetter DE, Katz E, Rothlin CV, Heinemann SF, Boulter J (2001) $\alpha 10$ : a determinant of nicotinic cholinergic receptor function in mammalian vestibular and cochlear mechanosensory hair cells. Proc Natl Acad Sci USA 98:3501-3506.

File SE (1992) Usefulness of animal models with newer anxiolytics. Clin Neuropharmacol [Suppl] 15:525A-526A.

File SE, Cheeta S, Kenny PJ (2000) Neurobiological mechanisms by which nicotine mediates different types of anxiety. Eur J Pharmacol 393:231-236.

Franceschini D, Orr-Urtreger A, Yu W, Mackley LY, Bond RA, Armstrong D, Patrick JW, Beaudet AL, De Biasi M (2000) Altered baroreflex in $\alpha 7$ deficient mice. Behav Brain Res 113:3-10.

Franceschini D, Paylor R, Broide R, Salas R, Bassetto L, Gotti C, De Biasi M (2002) Absence of $\alpha 7$-containing neuronal nicotinic acetylcholine receptors does not prevent nicotine-induced seizures. Brain Res Mol Brain Res 98:29-40.

Friedman BH, Thayer JF (1998) Anxiety and autonomic flexibility: a cardiovascular approach. Biol Psychol 49:303-323.

Gardiner SM (1977) The effects of short-term isolation on systolic blood pressure and heart rate in rats. Med Biol 55:325-329.

Girod R, Role L (2001) Long-lasting enhancement of glutamatergic synaptic transmission by acetylcholine contrasts with response adaptation after exposure to low-level nicotine. J Neurosci 21:5182-5190.

Gonzalez-Bono E, Moya-Albiol L, Salvador A, Carrillo E, Ricarte J, GomezAmor J (2002) Anticipatory autonomic response to a public speaking task in women: the role of trait anxiety. Biol Psychol 60:37-49.

Griebel G, Blanchard DC, Blanchard RJ (1996) Evidence that the behaviors in the Mouse Defense Test Battery relate to different emotional states: a factor analytic study. Physiol Behav 60:1255-1260.

Griebel G, Perrault G, Sanger DJ (1997) CCK receptor antagonists in animal models of anxiety: comparison between exploration tests, conflict procedures and a model based on defensive behaviours. Behav Pharmacol 8:549-560.

Griebel G, Belzung C, Perrault G, Sanger DJ (2000) Differences in anxietyrelated behaviours and in sensitivity to diazepam in inbred and outbred strains of mice. Psychopharmacology (Berl) 148:164-170.

Guidotti A, Dong E, Matsumoto K, Pinna G, Rasmusson AM, Costa E (2001) The socially-isolated mouse: a model to study the putative role of allopregnanolone and $5 \alpha$-dihydroprogesterone in psychiatric disorders. Brain Res Brain Res Rev 37:110-115.

Johansen-Berg H, Walsh V (2001) Cognitive neuroscience: who to play at poker. Curr Biol 11:R261-R263.

Kassel JD, Shiffman S (1997) Attentional mediation of cigarette smoking's effect on anxiety. Health Psychol 16:359-368.

Kassel JD, Unrod M (2000) Smoking, anxiety, and attention: support for the role of nicotine in attentionally mediated anxiolysis. J Abnorm Psychol 109:161-166.

Khiroug SS, Harkness PC, Lamb PW, Sudweeks SN, Khiroug L, Millar NS, Yakel JL (2002) Rat nicotinic ACh receptor $\alpha 7$ and $\beta 2$ subunits coassemble to form functional heteromeric nicotinic receptor channels. J Physiol (Lond) 540:425-434.

Labarca C, Schwarz J, Deshpande P, Schwarz S, Nowak MW, Fonck C, Nashmi R, Kofuji P, Dang H, Shi W, Fidan M, Khakh BS, Chen Z, Bowers BJ, Boulter J, Wehner JM, Lester HA (2001) Point mutant mice with hypersensitive $\alpha 4$ nicotinic receptors show dopaminergic deficits and increased anxiety. Proc Natl Acad Sci USA 98:2786-2791.

Leonard S, Adler LE, Benhammou K, Berger R, Breese CR, Drebing C, Gault J, Lee MJ, Logel J, Olincy A, Ross RG, Stevens K, Sullivan B, Vianzon R, Virnich DE, Waldo M, Walton K, Freedman R (2001) Smoking and mental illness. Pharmacol Biochem Behav 70:561-570.

Levin ED, Simon BB (1998) Nicotinic acetylcholine involvement in cognitive function in animals. Psychopharmacology (Berl) 138:217-230.

Lindstrom J, Anand R, Gerzanich V, Peng X, Wang F, Wells G (1996) Structure and function of neuronal nicotinic acetylcholine receptors. Prog Brain Res 109:125-137.

Marubio LM, del Mar Arroyo-Jimenez M, Cordero-Erausquin M, Lena C, Le Novere N, de Kerchove d'Exaerde A, Huchet M, Damaj MI, Changeux JP (1999) Reduced antinociception in mice lacking neuronal nicotinic receptor subunits. Nature 398:805-810.

Maschke M, Schugens M, Kindsvater K, Drepper J, Kolb FP, Diener HC, Daum I, Timmann D (2002) Fear conditioned changes of heart rate in 
patients with medial cerebellar lesions. J Neurol Neurosurg Psychiatry 72:116-118.

McGehee DS, Role LW (1995) Physiological diversity of nicotinic acetylcholine receptors expressed by vertebrate neurons. Annu Rev Physiol 57:521-546.

Morris JS, Smith KA, Cowen PJ, Friston KJ, Dolan RJ (1999) Covariation of activity in habenula and dorsal raphe nuclei following tryptophan depletion. NeuroImage 10:163-172.

Moulard B (2001) Ion channel variation causes epilepsies. Brain Res Brain Res Rev 36:275-284.

Naranjo JR (1985) Association between hypoalgesia and hypertension in rats after short-term isolation. Neuropharmacology 24:167-171.

Noteboom JT, Barnholt KR, Enoka RM (2001) Activation of the arousal response and impairment of performance increase with anxiety and stressor intensity. J Appl Physiol 91:2093-2101.

O'Connor MF, Allen JJ, Kaszniak AW (2002) Autonomic and emotion regulation in bereavement and depression. J Psychosom Res 52:183-185.

Orr-Urtreger A, Goldner FM, Saeki M, Lorenzo I, Goldberg L, De Biasi M, Dani JA, Patrick JW, Beaudet AL (1997) Mice deficient in the $\alpha 7$ neuronal nicotinic acetylcholine receptor lack $\alpha$-bungarotoxin binding sites and hippocampal fast nicotinic currents. J Neurosci 17:9165-9171.

Parrott AC (1995) Stress modulation over the day in cigarette smokers. Addiction 90:233-244.

Paylor R, Nguyen M, Crawley JN, Patrick J, Beaudet A, Orr-Urtreger A (1998) $\alpha 7$ nicotinic receptor subunits are not necessary for hippocampal-dependent learning or sensorimotor gating: a behavioral characterization of Acra7-deficient mice. Learn Mem 5:302-316.

Pellow S, Chopin P, File SE, Briley M (1985) Validation of open:closed arm entries in an elevated plus-maze as a measure of anxiety in the rat. J Neurosci Methods 14:149-167.

Picciotto MR (1995) Abnormal avoidance learning in mice lacking functional high-affinity nicotine receptor in the brain. Nature 374:65-67.

Picciotto MR, Brunzell DH, Caldarone BJ (2002) Effect of nicotine and nicotinic receptors on anxiety and depression. NeuroReport 13:1097-1106.

Pick CG, Peter Y, Paz L, Schreiber S, Gavish M, Weizman R (1997) Effect of the pregnane-related GABA-active steroid alphaxalone on mice performance in the staircase test. Brain Res 765:129-134.

Poth K, Nutter TJ, Cuevas J, Parker MJ, Adams DJ, Luetje CW (1997) Heterogeneity of nicotinic receptor class and subunit mRNA expression among individual parasympathetic neurons from rat intracardiac ganglia. J Neurosci 17:586-596.

Quick MW (1999) $\alpha 3 \beta 4$ subunit-containing nicotinic receptors dominate function in rat medial habenula neurons. Neuropharmacology 38:769-783.

Ramos A, Berton O, Mormede P, Chaouloff F (1997) A multiple-test study of anxiety-related behaviours in six inbred rat strains. Behav Brain Res 85:57-69.

Ross SA, Wong JY, Clifford JJ, Kinsella A, Massalas JS, Horne MK, Scheffer IE, Kola I, Waddington JL, Berkovic SF, Drago J (2000) Phenotypic characterization of an $\alpha 4$ neuronal nicotinic acetylcholine receptor subunit knock-out mouse. J Neurosci 20:6431-6441.

Russell MA (1989) Subjective and behavioural effects of nicotine in humans: some sources of individual variation. Addict Behav 14:335-341.

Rust G, Burgunder JM, Lauterburg TE, Cachelin AB (1994) Expression of neuronal nicotinic acetylcholine receptor subunit genes in the rat autonomic nervous system. Eur J Neurosci 6:478-485.

Rusted JM, Newhouse PA, Levin ED (2000) Nicotinic treatment for degenerative neuropsychiatric disorders such as Alzheimer's disease and Parkinson's disease. Behav Brain Res 113:121-129.

Salas R, Orr-Urtreger A, Broide R, Beaudet AL, Paylor R, De Biasi M (2003) The nicotinic acetylcholine receptor subunit $\alpha 5$ mediates acute effects of nicotine in vivo. Mol Pharmacol 63:1059-1066.

Salin-Pascual RJ, Moro-Lopez ML, Gonzalez-Sanchez H, Blanco-Centurion C (1999) Changes in sleep after acute and repeated administration of nicotine in the rat. Psychopharmacology (Berl) 145:133-138.
Sargent PB (1993) The diversity of neuronal nicotinic acetylcholine receptors. Annu Rev Neurosci 16:403-443.

Seguela P, Wadiche J, Dineley-Miller K, Dani JA, Patrick JW (1993) Molecular cloning, functional properties, and distribution of rat brain $\alpha 7$ : a nicotinic cation channel highly permeable to calcium. J Neurosci 13:596-604.

Sgard F, Charpantier E, Bertrand S, Walker N, Caput D, Graham D, Bertrand D, Besnard F (2002) A novel human nicotinic receptor subunit, $\alpha 10$, that confers functionality to the $\alpha 9$-subunit. Mol Pharmacol 61:150-159.

Shoaib M, Gommans J, Morley A, Stolerman IP, Grailhe R, Changeux JP (2002) The role of nicotinic receptor $\beta 2$ subunits in nicotine discrimination and conditioned taste aversion. Neuropharmacology 42:530-539.

Simiand J, Keane PE, Morre M (1984) The staircase test in mice: a simple and efficient procedure for primary screening of anxiolytic agents. Psychopharmacology 84:48-53.

Southwick SM, Paige S, Morgan III CA, Bremner JD, Krystal JH, Charney DS (1999) Neurotransmitter alterations in PTSD: catecholamines and serotonin. Semin Clin Neuropsychiatry 4:242-248.

Stewart SH, Karp J, Pihl RO, Peterson RA (1997) Anxiety sensitivity and self-reported reasons for drug use. J Subst Abuse 9:223-240.

Tassonyi E, Charpantier E, Muller D, Dumont L, Bertrand D (2002) The role of nicotinic acetylcholine receptors in the mechanisms of anesthesia. Brain Res Bull 57:133-150.

Tomizawa K, Katayama H, Nakayasu H (2001) A novel monoclonal antibody recognizes a previously unknown subdivision of the habenulointerpeduncular system in zebrafish. Brain Res 901:117-127.

Tornatzky W, Miczek KA (1995) Alcohol, anxiolytics and social stress in rats. Psychopharmacology 121:135-144.

Toubas PL, Abla KA, Cao W, Logan LG, Seale TW (1990) Latency to enter a mirrored chamber: a novel behavioral assay for anxiolytic agents. Pharmacol Biochem Behav 35:121-126.

van Gaalen MM, Stenzel-Poore MP, Holsboer F, Steckler T (2002) Effects of transgenic overproduction of CRH on anxiety-like behaviour. Eur J Neurosci 15:2007-2015.

Wang N, Orr-Urtreger A, Chapman J, Rabinowitz R, Nachman R, Korczyn $\mathrm{AD}$ (2002) Autonomic function in mice lacking $\alpha 5$ neuronal nicotinic acetylcholine receptor subunit. J Physiol (Lond) 542:347-354.

Wang X, Su H, Copenhagen LD, Vaishnav S, Pieri F, Shope CD, Brownell WE, De Biasi M, Paylor R, Bradley A (2002) Urocortin-deficient mice display normal stress-induced anxiety behavior and autonomic control but an impaired acoustic startle response. Mol Cell Biol 22:6605-6610.

Watkins LL, Blumenthal JA, Carney RM (2002) Association of anxiety with reduced baroreflex cardiac control in patients after acute myocardial infarction. Am Heart J 143:460-466.

Weizman R, Paz L, Backer MM, Amiri Z, Modai I, Pick CG (1999) Mouse strains differ in their sensitivity to alprazolam effect in the staircase test. Brain Res 839:58-65.

Xu W, Gelber S, Orr-Urtreger A, Armstrong D, Lewis RA, Ou CN, Patrick J, Role L, De Biasi M, Beaudet AL (1999a) Megacystis, mydriasis, and ion channel defect in mice lacking the $\alpha 3$ neuronal nicotinic acetylcholine receptor. Proc Natl Acad Sci USA 96:5746-5751.

Xu W, Orr-Urtreger A, Nigro F, Gelber S, Sutcliffe CB, Armstrong D, Patrick JW, Role LW, Beaudet AL, De Biasi M (1999b) Multiorgan autonomic dysfunction in mice lacking the $\beta 2$ and the $\beta 4$ subunits of neuronal nicotinic acetylcholine receptors. J Neurosci 19:9298-9305.

Yu W, Mackey LY, Xu W, Beaudet AL, De Biasi M (2000) Bradycardia and ventricular repolarization defects in mice lacking the $\alpha 3$ subunit of neuronal nicotinic acetylcholine receptors. In: The 10th Neuropharmacology Conference, p 113. New Orleans, Nov 2-4, 2000.

Zoli M, Le Novere N, Hill JA, Changeux JP (1995) Developmental regulation of nicotinic ACh receptor subunit mRNAs in the rat central and peripheral nervous systems. J Neurosci 15:1912-1939.

Zoli M, Picciotto MR, Ferrari R, Cocchi D, Changeux JP (1999) Increased neurodegeneration during ageing in mice lacking high-affinity nicotine receptors. EMBO J 18:1235-1244. 